\title{
Regulatory Developments in the Gig Economy: A Literature Review
}

\author{
Victory Haris Kusuma Wardhana ${ }^{1 *}$; Maria Grace Herlina ${ }^{2}$, \\ Sugiharto Bangsawan ${ }^{3}$; Michael Aaron Tuori ${ }^{4}$

\begin{abstract}
${ }^{1,2,3,4}$ Management Department, BINUS Business School Undergraduate Program, Bina Nusantara University
J1. Kebon Jeruk Raya No. 27, Kebon Jeruk, Jakarta 11530, Indonesia

${ }^{1}$ victory.haris@gmail.com; ${ }^{2}$ herlina01@binus.edu; ${ }^{3}$ Sugiharto.tanjung1@binus.ac.id; ${ }^{4}$ mtuori@binus.edu
\end{abstract}

Received: $13^{\text {th }}$ November $2020 /$ Revised: $25^{\text {th }}$ January $2021 /$ Accepted: $25^{\text {th }}$ January 2021

\begin{abstract}
How to Cite: Wardhana, V. H. K., Herlina, M. G., Bangsawan, S., \& Tuori, M. A. (2020). Regulatory developments in the gig economy: A literature review. The Winners, 21(2), 141-153. https://doi.org/10.21512/tw.v21i2.6758
\end{abstract}

\begin{abstract}
The emergence of the gig economy and its rapid growth was anticipated to play a big part in its economy. Despite the enormous benefits, the gig economy business model had also attracted numerous issues in many countries and regions. The research utilized a Systematic Literature Review (SLR) methodology by Snyder for analyzing regulation issues in the gig economy, which was divided into six steps, those were defining the central question, determining databases, using search string to find relevant keywords, extracting data, filtering data, and analyzing the findings to answer to the main question. The SLR results show licensing and misclassifications are the most dominant factors in gig economy, while regulatory issues such as safety, tax, externalities, wage, benefit, privacy, and discrimination area are other factors in it. The most popular platform types that attract regulators are work on demand, asset rental, and crowd-work.
\end{abstract}

Keywords: regulatory development, gig economy, Snyder literature review

\section{INTRODUCTION}

Rapid technology development in the $20^{\text {th }}$ Century has been causing massive disruptions to multiple industries and services, especially with digital platforms (Zutshi \& Grilo, 2019). The emergence of digital media creates a new field in innovative companies to develop a new market model. Transactions between supply and demand are mediated by peer-to-peer digital platforms (Koutsimpogiorgos et al., 2019) This new business model consists of a two-sided market mediated by online platforms that enable paid tasks or rented goods to be carried out by independent contractors and are called the "gig economy" (Koutsimpogiorgos et al., 2019). The gig economy also overlaps considerably with other concepts, such as the sharing economy, collaborative economy, and platform economy (Belk, 2014; Chalmers \& Matthews, 2019; Hyman, 2018).

The digital platform era is a catalyst for globalization that transcends national boundaries and fosters better cross-country flows (Lund \& Tyson, 2018). The expanse of digital technologies is changing all types of global flow, such as goods, services, money, and people. More corporations have turned into global supply chains in the last few years to survive crosscountry competition (Childerhouse \& Towill, 2003; Gereffi, 2011). Systemic and strategic coordination of global supply chains is crucial to increase competitive advantage (Council of Logistic Management, 2006; Mentzer, 2004). As gig economies have become increasingly powerful, every company operating in a global supply chain will need to align their supply chain strategy with the platform economy to help lower cost and differentiate service to its customers.

While businesses in the digital era are famous for demand spikes and crashes, gig workers' flexibility characteristic can overcome this inherent problem with current business management. Many companies have leveraged the gig economy as a solution for temporary hiring in their supply chain. Limiting new hires and utilizing freelance workers will create a more adaptive and flexible workforce in the supply chain without changing the business (Foote \& Folta, 2002; Tan et al., 2013). In this way, companies can maintain their competitive advantage by lowering costs and focusing on core business processes. Therefore, the gig economy has become more relevant and crucial, 
especially in managing global supply chains (Shukla, Garg, \& Agarwal, 2011).

In the upcoming years, the gig economy is anticipated to comprise a substantial portion of the economy with severe economic implications. The emergence of digital platforms mediating flexible labor fits in a long-term trend towards labor market flexibility and contingent work (Estlund, 2018; Hyman, 2018; Stanford, 2017). A report by The PricewaterhouseCoopers (PwC) emphasizes the potential of five key gig economy sectors (automotive, hospitality, finance, staffing, and media streaming) by forecasting earned sales revenue of US\$335 billion in 2025 compared with only US $\$ 15$ billion in 2015 (PwC, 2015). Of one the leading examples of a company in the gig economy are Uber, that offers ride-sharing services with over 3 million active drivers worldwide, completing more than 15 million trips each day (Bhuiyan, 2018). Another example is Airbnb that disrupted the hospitality industry by lowering prices per night by US $\$ 100$ compared to its traditional hotel competitors in major cities such as London, Paris, and New York City (Yaraghi \& Ravi, 2017).

In contrast to the enormous growth potential of the gig economy, the current regulation is considered to be unsuitable for the gig economy and its workers (Kennedy, 2016; Nurvala, 2015; Ljungholm, 2018). The crucial regulation issue is whether gig workers are more appropriately classified as independent contractors or as employees (Cunningham-Parmeter, 2016; Munkøe, 2017). Various lawsuits have alleged that gig economy platforms have misclassified their workers into independent contractors to evade employment laws (Cherry, 2016; Oei \& Ring, 2019; Schor, 2018). It is considered one of the main issues in the gig economy since worker classification eventually will affect many factors such as worker benefits, worker taxation, firm profitability, and other legal aspects as well (Munkøe, 2017; Oei \& Ring, 2019; Snider, 2018). Rogers (2015) states that in reality, while gig workers do not fit into either the employee or independent contractor categories, they should be treated as employees to counter the 'unequal bargaining power' between them and the platform company. Litigations and widespread confusion of how gig workers should be classified has also created new points of view on how a new hybrid category should be created, situated between the categories of employee and independent contractor (Cherry \& Aloisi, 2016; Kennedy, 2016). These issues about employment relationship are also closely linked with the well-being of gig workers, as research has shown that the average Uber driver only earns approximately minimum wage, and potentially less, after considering gas and the maintenance of their vehicle (Bogage, 2016; Pelzer et al., 2019).

A short history of how the word "gig" illustrates the gig economy is described by Parigi and Ma (2016). As a term that was initially used in the 1920 s by jazz musicians, the gig was slang for a recording session, live concert, or other musicians (Dalzell \& Victor, 2012). However, Jack Kerouac, for the first time, used the word gig outside the music industry, to describe a temporary job (Parigi \& Ma, 2016). Jones (2011) generally define that a gig is a single performance by a musician or a short-term job. A more "gig economy" relevant definition is stated by Bernhardt (2014) saying that gig is a unique subset of contingent work, which has grown since the most recent recession. However, absolute numbers are still small and difficult to track. Referring gig to contingent work was first used by journalist Tina Brown (McKinsey \& Company, 2016). Characteristics of contingent work reflect gig workers nowadays, such as temporary, contract based, and providing little or no benefits.

After reviewing characteristics from the word "gig", people can understand more about the gig economy's dynamics from the word "economy". Samuelson (1997) defines economy (originally from Greek 'oikonomos' - 'household management') as a study of how societies use scarce resources to produce commodities and distribute them among people (Samuelson, 1997). More straightforwardly, Marshall (2013) defines economy as a study of humankind in the ordinary business of life. It examines the part of individual and social action that is closely linked with the use of the material requisites of well-being. James (2014) adds a more general term of economy as a scope of production, distribution, and trade and the consumption of goods and services by different agents. In broader sense, economy is defined as a social domain that emphasizes the practices, discourses, and material expression associated with the production, use, and management of resources.

However, all these definitions do not cope well with the advancement of technology that develops new market models that establish entirely new concepts. Especially since the world is entering the Industry 4.0 era with the emergence of digital platforms (Zutshi \& Grilo, 2019), the power of knowledge and its influence in the economy become more apparent than ever, mainly in the case of the gig economy. A more relevant definition of the economy for the $21^{\text {st }}$ Century is the study of how humans use knowledge to identify resources and use these scarce resources to create, using expertise and commodities, and distribute them among people (Khumalo, 2012). In the case of the gig economy, implementation of this definition is how platform companies use information through their apps to bridge demand and supply between individuals to create new platform-based business models.

Given the novelty of the gig economy, there is no specific and shared definition of the gig economy for now (Schor, 2014). However in recent years, many scholars have created different constructs of the concept based on their discipline (Pettersen, 2017) as gig economy has captured more public interest (Kaine \& Josserand, 2019; Minifie, 2016). However, definitions of the gig economy are controversial and significantly various (Schor, 2014). Furthermore, the diversity of terminology makes it challenging for scholars to clearly define the concept.

Within the broader perspective of the concept, 
the gig economy involves two forms of work: crowdwork and work on demand (De Stefano, 2016; Veen et al., 2020). Crowd-work platforms trade primarily in microtasks as extremely parceled, menial, and monotonous activities that require some sort of judgment that computers are unable to execute (Irani, 2015; Lloyd, 2017). This category leverages specific professional expertise to deliver work online (Veen et al., 2020). Meanwhile, work on demand differs from crowd work as it involves real-world services rather than virtual tasks (Stewart \& Stanford, 2017). Jobs in this category are more related to traditional working activities such as transport, cleaning, and running errands offered and assigned through the platform (De Stefano, 2016).

Based on characteristics, the gig economy involves exchanging labor for money between individuals or organizations via digital platforms that facilitate providers and customers on a short-term and payment by task basis (Lepanjuuri, Wishart, \& Cornick, 2018). The OECD journal also similarly defines the gig economy, by limiting it as platforms that match workers on one side of the market to customers on the other side on a one-time basis (Schwellnus et al., 2019). The similarity between these two definitions is that they exclude people who use digital platforms to provide utilized assets that are not precisely labor-related, such as Airbnb (Lepanjuuri, Wishart, \& Cornick, 2018). It is argued that the utilization of assets is more suited to the sharing economy as a broader scope (Dazzi, 2019). Meanwhile, the gig economy is only focused on work through online platforms (Brinkley, 2016). However, many scholars and journalists have already included Airbnb as a part of the gig economy rather than the sharing economy (Newcomer, 2020; Liu, 2019; Bernick, 2019; Oei \& Ring, 2019; Parigi \& Ma, 2016).

At first, 'sharing economy' has been the more dominant term to describe new firms, especially platform businesses, since 2010 (Sundararajan, 2014). The gig economy's shift derives from an emerging sense that the sharing economy is not a proper name for an apparent commercial sector ( $\mathrm{Li} \& \mathrm{Ma}, 2019$; Slee, 2017). There are also legal reasons regarding the term 'sharing economy,' especially in ambiguity on worker classification, taxation, public accommodation law, and other regulations behind the word (Berke, 2016). It is argued that the sharing economy definition is no longer useful in scoping the gig economy (Oei \& Ring, 2019). Therefore, it is proposed that the gig economy definition for the research includes asset rental because hospitality industry platforms such as Airbnb have a far-reaching impact (Armitage \& Cordova, 2017; Kaplan \& Nadler, 2015; Wegmann $\&$ Jiao, 2017). A relevant definition for gig economy is a new business model consisting of a two-sided market mediated by online platforms. It enables paid tasks or rented goods to be carried out by independent contractors (Koutsimpogiorgos et al., 2019).

After reviewing several definitions, the existing framework and the substantial differences in the gig economy definition can be seen (Kuhn \& Maleki,
2017; Stewart \& Stanford, 2017). Despite the lack of agreement between researchers, it is still possible to differentiate four gig economy (Koutsimpogiorgos et al., 2019). As explained in Figure 1, there are four dimensions.

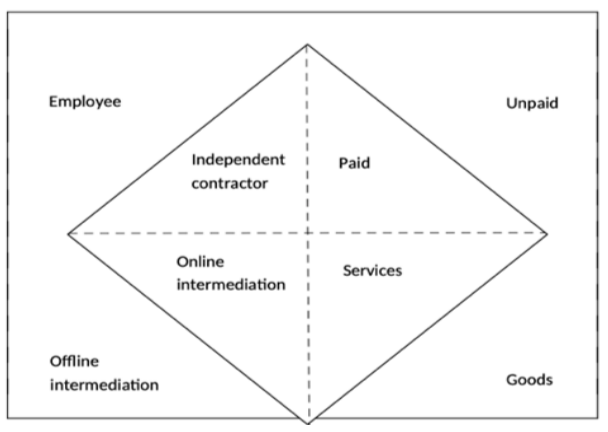

Figure 1 Narrow and Broader Characteristics of the Gig Economy

(Koutsimpogiorgos, Slageren, \& Herrmann, 2019)

First, online platform versus offline intermediation is where most scholars define the gig economy's main feature as online platforms (Lepanjuuri, Wishart, \& Cornick, 2018; Schwellnus et al., 2019). However, there are opposing points of view that do not consider online platforms as a criterion. Instead, they understand the gig economy as a phenomenon which includes all flexible work arrangements of independent contractors (Friedman, 2014; Kuhn \& Maleki, 2017). The second dimension is independent contractor versus employee, which many consider one of the main issues in the gig economy (De Stefano, 2016; Oei \& Ring, 2019; Risak \& Prassl, 2016). Worker classification affects many factors such as workers benefits, workers taxation, firm profitability, and other legal aspects (Oei \& Ring, 2019).

The third one is paid versus unpaid, in which most definitions solely focus on the gig economy as paid work (De Stefano, 2016; Kuhn \& Maleki, 2017; Oei, 2018). However, there is a substantial component of unpaid work associated with paid work in the gig economy, such as outstanding waiting time for couriers (Koutsimpogiorgos et al., 2019). The last dimension is services versus goods, in which most authors mainly exclude rented goods platforms such as Airbnb in the gig economy (Lepanjuuri, Wishart, \& Cornick, 2018; Schwellnus et al., 2019). However, it is argued that rented goods, such as becoming an Airbnb tenant, also require accommodation services (Frenken, et al., 2019).

Aside from the dimensions proposed by Koutsimpogiorgos et al. (2019) to define the gig economy, another framework by Dazzi (2019) is considered to be relevant as well. The framework combines popular dimensions from various authors (De Stefano, 2016; Graham \& Shaw, 2017; McKinsey \& Company, 2016) and includes asset rental as part 
of the gig economy. Through the framework, Dazzi (2019) states that the gig economy involves three forms of work. The first one is crowd-work, in which many people work on individual tasks for a company similar to self-employed freelancers (Jäger et al., 2019). This category leverages specific professional expertise to deliver work online (Veen et al., 2020), such as programmers, freelancers, professionals, or individuals that work from home. These are platforms that operate globally like UpWork, Amazon Mechanical Turk, Freelancer, and others.

The second one is work on demand. Each task is involved with real-world services rather than virtual studies (Stewart \& Stanford, 2017), usually related to traditional working activities such as transport, cleaning, and running errands (De Stefano, 2016). These are platforms that operate locally such as Uber, Lyft, Grab, and others. The last one is asset rental, in which the focus is on the renting and leasing of goods and property. A famous example is Airbnb, which provides an online accommodation platform connecting tourists with property owners (Coyle \& Yeung, 2017).

To understand more about how the platforms work in the gig economy, it is essential to look at the platform model by Constantiou characterized by the control exerted by platform owners and the rivalry among platform participants (Constantiou et al., 2017; Wiener, Cram, \& Benlian, 2019). Based on these two dimensions, Constantiou et al. (2017) differentiates among four types of platforms as seen in Figure 2: 1) Gardeners, which focus on offering an infrastructure for a community to use while setting only minimum standards for platform participation and fostering low rivalry among participants; 2) Chaperones, characterized by a low standard created by platform owners and intense rivalry among its participants; 3) Franchisers, which features ride-hailing platforms such as Uber, which exercise tight control and promote intense rivalry among drivers; 4) Principals, which exercise tight control and low rivalry among its participants to mitigate risk and maintain costs.

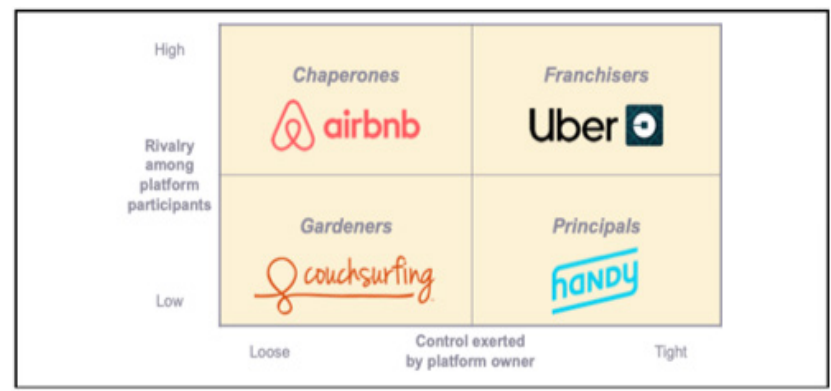

Figure 2 Typology of Gig Economy Platforms (Constantiou et al., 2017; Wiener et al., 2019)

Another different but similar model by Kalleberg \& Dunn (2016) is used to control and wages for the primary dimension to determine job quality types. The control dimension is different from the Constantine model. Instead of referring to control exerted by a company, it relates to worker control over work content and timing. The second dimension is the wage level, usually defined by the skill required to do the work.

There are four types of platforms, as shown in Figure 3. The first platform is High Wage/High Worker Control characterized by online freelance platforms such as Upwork. Employers usually offer relatively high skilled jobs that pay relatively high wages, such as software development or design. Secondly, High Wage/Low Worker Control are characterized by local aspects such as transportation and delivery tasks. These platforms typically operate in big cities, so workers can generally earn higher than minimum wage. However, tight regulations are usually exerted by the venue, leaving workers with lower control. Thirdly, Low Control/Low Wages are characterized by crowd work, for example, Amazon Mechanical Turk. Employers usually set the wage without the workers' input but permit workers to reject the tasks outright. Tasks in crowd work are generally straightforward and hence pay very little. The last one is High Control/ Low Wages. In this category, there are no identified platforms as of now.

Considering the gig economy's relevance with supply chain optimization, it is essential to understand more about the gig economy's current state and potential problems. Therefore, the research aims to analyze regulation implementation in the gig economy based on prior study and regulation. It is vital to fit clarification the characteristics and dimensions of the gig economy to go deeper into the regulatory issues.

The research begins with a brief literature review of the gig economy's origins and definitions, followed by topics such as existing models and dimensions.

\begin{tabular}{|c|c|}
\hline $\begin{array}{l}\text { High Wages/Low Worker Control } \\
\text { - Transportation Plattorms } \\
\text { - Delivery/Home Task Plattorms }\end{array}$ & $\begin{array}{l}\text { High Wages/High Worker Control } \\
\text { - Online Freelance Plattorms }\end{array}$ \\
\hline $\begin{array}{l}\text { Low Wages/Low Worker Control } \\
\text { - Crowdwork Plattorms }\end{array}$ & $\begin{array}{l}\text { Low Wages/High Worker Control } \\
\text { - None }\end{array}$ \\
\hline
\end{tabular}

Figure 3 Job Quality Types in the Gig Economy (Kalleberg \& Dunn, 2016)

\section{METHODS}

The research focuses on finding related studies in the regulation of the gig economy. It is utilized by a SLR technique by Snyder (2019) for analyzing regulation implementation in the gig economy based on prior study and exploration. This technique is divided into six steps: 1) defining the central question as explained in the introduction; 2) determining databases; 3) using search string to find relevant 
keywords; 4) extracting data; 5) filtering data; and 6) analyzing the findings to answer to the main question.

Before conducting a keyword search, it is essential to determine the sources that will be used with search process. These are the following databases for the SLR: 1) Science Direct (www.sciencedirect. com); 2) Wiley Online Library (www.onlinelibrary. wiley.com); 3) Emerald Insight (www.emeraldinsight. com); 4) Springer Link (www.link.springer.com); 5) Sage Hub (www.journals.sagepub.com); 6) Taylor Francis Online (www.tandfonline.com); 7) AISEL Library (www.aisel.aisnet.org); and 8) IEEEXplore Digital Library (www.ieeexplore.ieee.org)

The search string is conducted in the content and abstract of the selected sources. The defined search string is: ("gig economy" OR "platform economy" OR "sharing economy" OR "collaborative economy") AND ("regulation" OR "law" OR "rule" OR "legal" OR "misclassification").

The SLR process started with 5.783 research narrowed into 134 reviews by filtering relevant titles. From the previous filtering, 54 research are found and read thoroughly to evaluate the content. Research with no correlation with the topic are excluded. Subsequently, 46 studies are included in the analysis. Table 1 summarizes the data extraction process.

Table 1 Data Extraction Stages

\begin{tabular}{lcccc}
\hline Sources & Found & $\begin{array}{c}\text { Candidate } \\
\text { (title) }\end{array}$ & $\begin{array}{c}\text { Candidate } \\
\text { (abstract) }\end{array}$ & Selected \\
\hline $\begin{array}{l}\text { Science } \\
\text { Direct }\end{array}$ & 1.820 & 29 & 12 & 11 \\
Wiley & 772 & 19 & 10 & 9 \\
Online & & & & \\
Library & & 8 & 3 & 1 \\
Emerald & 500 & 17 & 7 & 6 \\
Insight & & & & \\
Springer & 1.251 & 26 & 14 & 13 \\
Link & & 21 & 6 & 5 \\
Sage Hub & 699 & & & \\
Taylor & 533 & & 1 & 1 \\
Francis & & 7 & 1 & 0 \\
Online & & 7 & $\mathbf{5 4}$ & $\mathbf{4 6}$ \\
AISEL & 201 & $\mathbf{1 3 4}$ & & \\
IEEE & 7 & & & \\
\hline Total & $\mathbf{5 . 7 8 3}$ & & & \\
\hline
\end{tabular}

\section{RESULTS AND DISCUSSIONS}

There are 46 identified papers which are based on regulatory issues concerning the gig economy. This section provides the SLR results by presenting publication trends, publishing outlets, and regulation mapping based on the literature.

The frequency of studies published between
2016-2020 can be seen in Table 2 and Figure 4. The researchers see that the gig economy, especially concerning regulation, is a recent phenomenon since 2016. The most productive year is 2019, with 20 publications that account for $43 \%$ of all studies. The increase in publications for 2019 is caused mainly by studies analyzing emerging regulations in China, Europe, and Southeast Asia. The second most productive year is 2017, with 14 publications that account for $30 \%$ of all studies. The increase in publications for 2017 is caused mainly by research analyzing Europe's regulations, as scholars become more concerned about the rapid growth of the gig economy in the region.

Table 2 Frequency of Studies

\begin{tabular}{ccc}
\hline Year & $\#$ & \% \\
\hline 2016 & 2 & $4,35 \%$ \\
2017 & 14 & $30,43 \%$ \\
2018 & 7 & $15,22 \%$ \\
2019 & 20 & $43,48 \%$ \\
2020 & 3 & $6,52 \%$ \\
\hline Total & $\mathbf{4 6}$ & $\mathbf{1 0 0 \%}$ \\
\hline
\end{tabular}

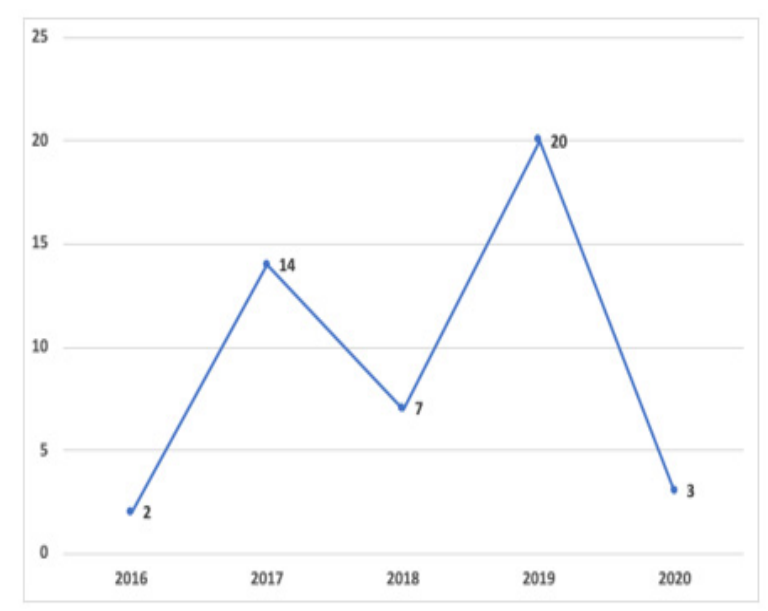

Figure 4 Study Trend over the Year

Table 3 shows the use of some of the most famous journals in the review such as Transfer, which is a journal about European review of labor and research (4 papers), Computer Law \& Security Review (3 papers), Environmental Innovation and Societal Transition (2 papers), and Transportation Research Procedia (2 papers). The rest of the journal articles or conference proceedings used in this literature review consist of one paper only, as seen in Table 3. Overall, 39 journals are used in the research.

After filtering and analyzing the systematic literature review, the results are decided to use regulation mapping based on three dimensions, 
including platform types, scholar perspectives, and regulation issues. This way will help comprehend the current trends of regulation, especially on the gig economy.

It is relevant to define the types of platforms to identify which kind of media attract regulators' attention the most and why. For platform types within the gig economy, the research uses Dazzi's framework combining the popular dimensions from several researchers (De Stefano, 2016; Graham \& Shaw, 2017; McKinsey \& Company, 2016). This framework classifies the gig economy platform into three types.

Table 3 Source of Publications

\begin{tabular}{|c|c|c|}
\hline Journal / Conference Name & \# & $\%$ \\
\hline Transfer & 4 & $8,70 \%$ \\
\hline Computer Law \& Security Review & 3 & $6,52 \%$ \\
\hline Environmental Innovation and Societal Transitions & 2 & $4,35 \%$ \\
\hline Transportation Research Procedia & 2 & $4,35 \%$ \\
\hline Competition and Regulation in Network Industries & 1 & $2,17 \%$ \\
\hline Policy Sciences & 1 & $2,17 \%$ \\
\hline Journal of Law and Society & 1 & $2,17 \%$ \\
\hline Australian Journal of Public Administration & 1 & $2,17 \%$ \\
\hline Strategic Change & 1 & $2,17 \%$ \\
\hline Critical Criminology & 1 & $2,17 \%$ \\
\hline Journal of Cleaner Production & 1 & $2,17 \%$ \\
\hline Economic Affairs & 1 & $2,17 \%$ \\
\hline New Labor Forums & 1 & $2,17 \%$ \\
\hline Economic and Labour Relations Review & 1 & $2,17 \%$ \\
\hline Regional Studies, Regional Science & 1 & $2,17 \%$ \\
\hline Environment and Planning A & 1 & $2,17 \%$ \\
\hline Challenge & 1 & $2,17 \%$ \\
\hline Case Studies on Transport Policy & 1 & $2,17 \%$ \\
\hline Journal of Business Ethics & 1 & $2,17 \%$ \\
\hline European Journal of Social Security & 1 & $2,17 \%$ \\
\hline Journal of Economics and Management Strategy & 1 & $2,17 \%$ \\
\hline European Labour Law Journal & 1 & $2,17 \%$ \\
\hline Land Use Policy & 1 & $2,17 \%$ \\
\hline GeoJournal & 1 & $2,17 \%$ \\
\hline Policy and Internet & 1 & $2,17 \%$ \\
\hline Industry and Innovation & 1 & $2,17 \%$ \\
\hline Political Quarterly & 1 & $2,17 \%$ \\
\hline Information Technology and Tourism & 1 & $2,17 \%$ \\
\hline Research in the Sociology of Organizations & 1 & $2,17 \%$ \\
\hline Intereconomics & 1 & $2,17 \%$ \\
\hline The Economic and Labour Relations Review & 1 & $2,17 \%$ \\
\hline Transportation Research Part B: Methodological & 1 & $2,17 \%$ \\
\hline Transnational Legal Theory & 1 & $2,17 \%$ \\
\hline Urban Policy and Research & 1 & $2,17 \%$ \\
\hline $40^{\text {th }}$ International Conference on Information Systems, ICIS 2019 & 1 & $2,17 \%$ \\
\hline International Journal of Contemporary Hospitality Management & 1 & $2,17 \%$ \\
\hline Urban Studies & 1 & $2,17 \%$ \\
\hline International Journal of Tourism Cities & 1 & $2,17 \%$ \\
\hline International Review of Law, Computers and Technology & 1 & $2,17 \%$ \\
\hline Total & 39 & $100 \%$ \\
\hline
\end{tabular}


Crowd-work is a type of medium in which many people work on individual tasks for a company that is similar to a self-employed freelancer. It used specific professional expertise to deliver online (Jäger et al., 2019; Veen et al., 2020). Some popular crowd-work platforms are UpWork, Amazon Mechanical Turk, and Freelancer. Work on demand is a type of platform that involves real-world service rather than virtual tasks. It is usually more related to traditional working activities such as transport, cleaning, and running errands (De Stefano, 2016; Stewart \& Stanford, 2017). Some famous work on-demand platforms are Uber, Lyft, Grab, and Gojek. Asset Rental is a type of platform that involves the renting and leasing of goods and property. The most popular asset rental platform is Airbnb which provides an online accommodation application connecting tourists with property owners (Coyle \& Yeung, 2017).

Scholar perspectives are essential to identify the points of view regarding the gig economy, as there is an on-going argument among scholars between those arguing against regulations or in favor of some rules (Codagnone \& Martens, 2016; Pawlicz, 2019). Regarding rules in the gig economy, it is decided to classify three perspectives - pros, cons, and neutral. In pros, scholars who agree with the gig economy concept support regulative leniency towards the gig economy platform. Arguments against regulation from this perspective are that strictness can limit innovation, protect incumbents, not customers, and limit property rights (Pawlicz, 2019). In cons, scholars who disagree with the gig economy concept support some regulations or propose a complete ban towards gig economy platforms. The gig economy rules can cause unfair competition, negative externalities, information asymmetries, and intermediaries monopolistic (Pawlicz, 2019). Neutral is a perspective where scholars observe the gig economy objectively and fairly, considering its advantages and disadvantages without choosing sides. Therefore, they usually try to present a balanced argument towards platform regulation.

The worldwide emergence of the gig economy platform has turned attention to these business models (Belk, 2014; Belk et al., 2019). Defining and classifying regulatory issues are crucial to understand the current situation concerning regulation in the gig economy. Each country and city have their unique issues regarding platform legitimacy. The research classifies regulatory matters regarding the gig economy into several categories as seen in Figure 5: 1) licensing; 2) externality; 3) misclassification; 4) benefits; 5) wages; 6) taxes; 7) safety; 8) privacy; and 9) discrimination.

Licensing is needed as local regulation that has not kept up with platform business models (Kennedy, 2016; Nurvala, 2015; Ljungholm, 2018), license to operate becomes a significant issue encountered by many platforms, especially with platform types that are more involved with local regulation, such as work on demand and asset rental. Licensing requirements are often accompanied by quality and safety standards that are applied to incumbent industries, but usually, the gig economy platforms appeal that they are merely acting as a technological platform, not a service company (Codagnone et al., 2018; McKee, 2017; Yuana et al., 2019). Applying traditional regulation to the gig economy platforms usually mix political process with incumbent industries and on-going concern regarding a level playing field (Jiang \& Zhang, 2019; Sinclair, 2016; Williams \& Horodnic, 2017).

Externality issues are costs that affect a third party caused by gig economy activity such as noise, traffic, disturbing residential area, unsafe and uninsured cars, increased cost of housing, and others adverse effects affecting a third party (Codagnone et al., 2018; McKee, 2017; Munkøe, 2017; Park, 2019). In various research, externalities have become dominant topics in the gig economy.

Misclassification concerns whether gig workers are more appropriately classified as independent contractors or as employees and have sparked fierce debate globally (Cunningham-Parmeter, 2016; Munkøe, 2017; Zhang, 2019). Various lawsuits have alleged that gig economy platforms have misclassified their worker into independent contractors to evade employment law (Cherry, 2016; Oei \& Ring, 2019; Schor, 2018). There are also growing recommendations from scholars to create a hybrid category, situated between the employee and independent contractor categories (Cherry \& Aloisi, 2016; Frenken et al., 2019; Kennedy, 2016).

The scope of services varies a great deal, and as for now, many workers in the gig economy receive few benefits or not at all. (Etzioni, 2018). Benefits are usually linked with misclassification as employee benefits are typically tied to a worker's legal status (Cherry, 2016; Zwick, 2018). It is argued that platform companies use independent contractor status as a tool to evade essential benefits such as overtime pay, health care, vacation days, and unemployment insurance (Goodwin \& Maconachie, 2011; Minter, 2017; Snider, 2018).

Wages of gig workers is related to classification issues about employment relationships, considering independent contractor status is not covered with minimum wages and other requirements under traditional employment law (Campbell \& Peeters, 2008; Dudley et al., 2017; Holley, 2014; Minter, 2017; Ravenelle, 2019). Many scholars have started to impose minimum wage regulations for gig workers as many platforms are considered to pay below minimum wage (Bogage, 2016; Etzioni, 2018; Li et al., 2019).

Taxes have become famous and controversial topics in regulating gig economy platforms (Oei \& Ring, 2019; Zhang \& Kien, 2019). It is argued that income accumulated from media largely escapes tax authorities' attention, as most gig workers fail to report income from platforms (Berger et al., 2020; Codagnone et al., 2018; Groen \& Maselli, 2016; Munkøe, 2017).

Safety issues concern two sides of the economic platform in the gig economy. Those are consumer and labor protection (Codagnone et al., 2018; Frenken et 
al., 2019). As gig platforms can only work so far with some trust established between strangers, media starts to recognize the importance of safety, focusing on user liability and insurance (Codagnone et al., 2018; Munkøe, 2017). Recently safety issues regarding customer protection have become one of the popular topics in the gig economy. It is a crucial factor of public interest (Frenken et al., 2019; McKee, 2017; Zhang \& Kien, 2019).

Privacy is needed because all gig economy platforms collect personal data, so it raises questions about confidentiality given some of these data (Codagnone et al., 2018; Frenken et al., 2019; McKee, 2017). There has been a strong allegation against various platforms regarding privacy (Zhang, 2019; Zhang \& Kien, 2019). However, there are still very few regulations addressing privacy issues directly, and platforms take initiatives to set their own rules of play by using contractual terms between user and platform (McKee, 2017; Wahyuningtyas, 2019).

As for now, many workers in the gig economy are not protected from discrimination (Etzioni, 2018; McKee, 2017). Although various platforms have anti-discrimination policies, there is growing evidence that platform business models' nature may enable person-to-person discrimination either through rejecting other user service requests or through rating systems (Edelman \& Luca, 2014; Einav, Farronato, \& Levin, 2016). Following the three dimensions stated earlier, the researchers analyze 46 studies about regulation to decide which platform types to focus, understand writers' perspectives about the gig economy, and identify what types of regulatory issues are being mentioned. There are three dimensions to analyze regarding regulation in the gig economy. The researchers are going to break down each of the three measurements to examine the result.

The first dimension is the platform type to identify which platform types attract the regulator's attention the most. As shown in Figure 5, the dominant platform type that attracts the regulator's attention is to work on demand. Work on demand's popularity regarding regulation issues can be explained by the work's physical nature that attracts more local topics such as licensing and misclassification. Next is asset rental which Airbnb represents as the most popular platform type. Airbnb has successfully attracted regulators regarding externality issues created by the platform (Lima. 2019). The least popular platform concerning regulators is crowd-work, but it is not surprising that the crowd works entirely online. It results in less attention from local regulators, unlike work on demand and asset rental platforms that are more physical.

The second dimension is the scholar perspective to identify scholar points of view regarding the gig economy and its correlation with regulation. Based on Figure 5, researchers conclude that scholars' points of view regarding the gig economy and regulation are evenly distributed among the 46 studies. Scholars who disagree with the gig economy are rooting for stricter regulation, stressing the business model's neoliberal and exploitative nature. Meanwhile, scholars who agree with the gig economy concept are rooting for better code to accommodate the platform business model.

The third dimension is regulation issues to help define the current situation and trends concerning
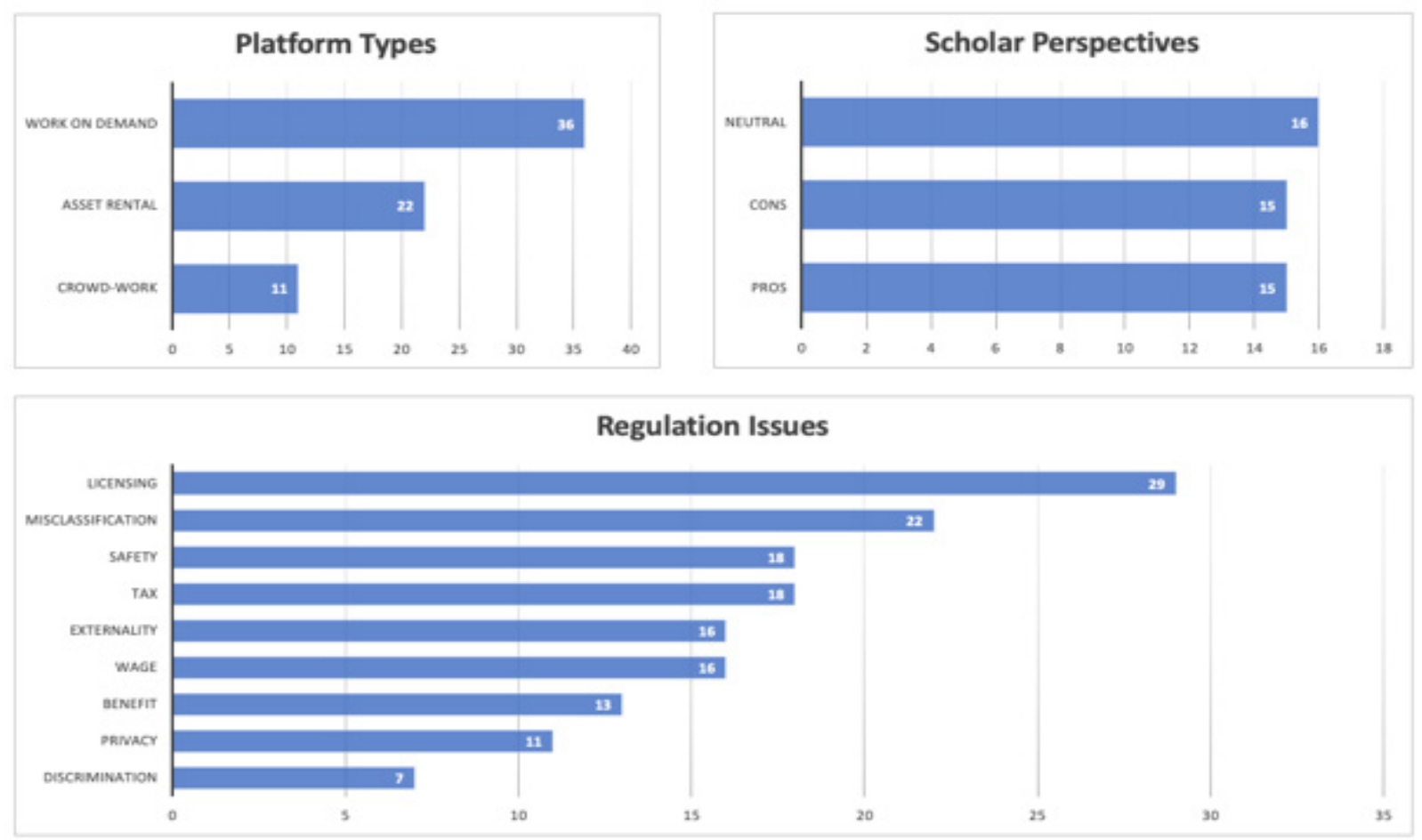

Figure 5 Three Dimensions of Analysis in Gig Economy 
regulation in the gig economy. As shown in Figure 5 , it can be seen that license is the highest regulation issue. Licensing frequently occurs since it has become fundamental to platform growth to have licenses for operating in a city or country, especially with work on demand and asset rental platforms that usually have standards and regulations applied to incumbent companies.

Next is misclassification, referring to the employment relationship ambiguity of gig workers and media. The importance of the misclassification issue is explained by the nature of the employment relationship that will define the outcome of the other problems, such as benefit and wage. The next points are safety and tax, which have the same literature frequency, as seen in Figure 5. Safety concerns in the gig economy are crucial because it is directly affecting the platform's reputation. Therefore, platforms are developing many policies to ensure the safety of customers and workers. The tax has also become a highlighted issue by authorities, as most gig workers do not report income from platforms.

Furthermore, tax authorities do not have access to detailed data about workers' income through the platform which is eventually related to privacy issues. The next two issues are externalities and wages which have the same literature frequency as seen in Figure 5. While externalities can also happen on work on-demand platforms, the issue is mostly highlighted on asset rental platforms. Regarding wages, it usually depends on the outcome of the classification issue about the employment relationship. The next issue is the benefit, which also relies on the creation of the classification issue. Next is privacy, followed by discrimination issues. Privacy and discrimination are seldom addressed in research since traditional regulation has not kept up with these purely contemporary issues caused by platform business models.

\section{CONCLUSIONS}

The gig economy has become more relevant than ever, especially with supply chain management integrating flexible workforce to gain competitive advantage. It is crucial to analyze the gig economy's current situation to understand where the concept stands fully. Given that many regulations are not suitable for the gig economy concept and its workers, this will eventually create many issues for gig economy platforms and regulators in many countries. The research aims to address the regulatory problems within the gig economy using the systematic literature review (SLR) methodology.

According to the SLR analysis, licensing (found in 29 studies) and misclassification (found in 22 reviews) are the most dominant regulatory issues regarding the gig economy. License to operate has become a significant issue worldwide, especially in demand and asset rental platforms, because of regulators' inability to address this entirely new gig economy and business model. The misclassification of gig workers has become a significant issue since the outcome will affect other vital matters, such as benefits and wages. Besides licensing and misclassification, other things are safety, tax, externalities, salaries, benefits, privacy, and discrimination.

Moreover, the most popular platform types that attract regulators are work on demand, followed by asset rental, and the last is crowd-work. The dominance of work on demand and asset rental platforms in research on regulation is caused by both platform types' physical nature and attracting more local regulators. However, regulators and scholars also need to focus their attention on crowd-work platforms as they may have many unaddressed labor issues.

The integration of the gig economy in supply chain management will be ineffective if the licensing issues are not addressed. Legal regulations' incapability to address this issue has caused significant drawbacks among several stakeholders and economic efficiency. To integrate the gig economy into business management, it needs to pay close attention to the platform's legitimacy or company that they intend to use. This way, the integrated supply chain can be safe from litigation and bad publicity. Furthermore, more legitimate platforms will ensure efficiency and effectiveness in the system.

Besides creating legal frameworks for platforms, technology's importance also has to overcome several gig economy issues, especially concerning misclassification. Gig workers are generally classified as independent contractors, which awards them unequal bargaining power. Social web software should be introduced to accommodate workers to form an online community tailored for gig workers. Therefore, gig workers can increase their bargaining power and other advantages, such as networking and skill development. Another critical issue that can be addressed with technology is privacy. While data in gig platforms contain sensitive information, there are no rules regarding data safety and how company platforms can use this information. Therefore, there is a need for data protection standards developed by regulators to overcome data management issues.

The research has several limitations. Based on the nature of the systematic literature review methodology, restricted access to the number of databases and research has become one limitation. The next hurdle is the characteristic of the general studies used for the SLR, which is dominated by the western world, such as countries from North America, Europe, and Australia. Regulatory issues regarding the gig economy may apply differently in developing countries from Asia, Africa, and South America.

The research proposes a direction of future research regarding regulations in the gig economy based on theoretical work with further fact-based evidence. Therefore, future research is proposed to use the development of the research as an instrument to be tested with an empirical approach. 


\section{REFERENCES}

Armitage, A. \& Cordova, A. K. (2017, August 23). Designthinking: The answer to the impasse between innovation and regulation. UC Hastings Research Paper No. 250, SSRN Electronic Journal. https://doi. org/10.2139/ssrn.3024176

Belk, R. (2014). You are what you can access: Sharing and collaborative consumption online. Journal of Business Research, 67(8), 1595-1600. https://doi. org/10.1016/j.jbusres.2013.10.001.

Belk, R., Eckhardt, G., Bardhi, F., \& Mikołajewska-Zając, K. (2019). The rhetoric of sharing: Managerial literature on the sharing economy. Handbook of the Sharing Economy, October 2019, 362-374. https:// doi.org/10.4337/9781788110549.00039.

Berger, L., Guo, L., \& King, T. (2020). Selfish sharing? The impact of the sharing economy on tax reporting honesty. Journal of Business Ethics, 167(4), 181205. https://doi.org/10.1007/s10551-019-04409-z.

Berke, D. (2016). Products liability in the sharing economy. Yale Journal on Regulation, 33(2), 603653. http://www.slate.com/articles/technology/ technology/2012/03/relayrides.

Bernhardt, A. (2014). IRLE labor standards and the reorganization of work: Gaps in data and research labor standards and the reorganization of work: Gaps in data and research. IRLE Working Paper No. 100114. https://escholarship.org/content/qt3hc6t3d5/ qt3hc6t3d5.pdf.

Bernick, M. (2019, 12 February). The gig economy rapidly evolves. Forbes. https://www.forbes.com/sites/ michaelbernick/2019/02/12/the-gig-economyrapidly-evolves/\#20775d6664bb.

Bhuiyan, J. (2018, 05 January). Uber powered four billion rides in 2017. It wants to do more-and cheaper-in 2018. Recode. https://www.vox. com/2018/1/5/16854714/uber-four-billion-ridescoo-barney-harford-2018-cut-costs-customerservice.

Bogage, J. (2016). How much Uber drivers actually make per hour. The Washington Post. https:// www.washingtonpost.com/news/the-switch/ wp/2016/06/27/how-much-uber-drivers-actuallymake-per-hour/.

Brinkley, I. (2016). In Search of the Gig Economy. London: The Work Foundation.

Campbell, I. \& Peeters, M. (2008). Low pay, compressed schedules and high work intensity: A study of contract cleaners in Australia. Australian Journal of Labour Economics, 11(1), 27-46. https://econpapers.repec.org/article/ozljournl/ v_3a11_3ay_3a2008_3ai_3a1_3ap_3a27-46.htm.

Chalmers, D. \& Matthews, R. (2019). Good to be bad: Should we be worried by the sharing economy? Strategic Change, 28(6), 403-408. https://doi. org/10.1002/jsc. 2295 .

Cherry, M. A. (2016). Beyond misclassification: The digital transformation of work. Comparative Labor Law \& Policy Journal. Forthcoming, Saint Louis U. Legal Studies Research Paper No. 2016-2. https://ssrn. com/abstract $=2734288$

Cherry, M. A. \& Aloisi, A. (2016). 'Dependent contractors' in the Gig economy: A comparative approach. 66 American Univ. L. Rev. 635. Saint Louis U. Legal Studies Research Paper No. 2016-15. https://doi. org/10.2139/ssrn.2847869.

Childerhouse, P. \& Towill, D. R. (2003). Simplified material flow holds the key to supply chain integration. Omega, 31(1), 17-27. https://doi.org/10.1016/ S0305-0483(02)00062-2.

Codagnone, C., Karatzogianni, A., \& Matthews, J. (2018). Rhetoric, reality, impacts and regulation in labour intermediation platforms. Platform Economics: Rhetoric and Reality in the 'Sharing Economy', pp. 35-71. https://doi.org/10.1108/978-1-78743-809520181002

Codagnone, C., \& Martens, B. (2016). Scoping the sharing economy: Origins, definitions, impact and regulatory issues. Institute for Prospective Technological Studies Digital Economy Working Paper 2016/01. https://doi.org/10.2139/ssrn.2783662.

Constantiou, I., Marton, A., \& Tuunainen, V. K. (2017). Four models of sharing economy platforms. MIS Quarterly Executive, 16(4), 236-251. https:// research.aalto.fi/en/publications/four-models-ofsharing-economy-platforms.

Council of Logistic Management. (2006). What its all about. In P. M. Swamidass (Eds.), Encyclopedia of Production and Manufacturing Management (pp. 134-135). US: Springer. https://doi.org/10.1007/14020-0612-8_194.

Coyle, D., \& Yeung, T. Y-C. (2017). Understanding AirBnB in fourteen European cities. The Jean-Jacques Laffont DIGITAL CHAIR. Working Papers. https:// www.researchgate.net/profile/Timothy-Yu-CheongYeung/publication/333021103_Understanding AirBnB_in_Fourteen_European_Cities/ links/5cd6 c003299bf14d9589eded/UnderstandingAirBnB-in-Fourteen-European-Cities.pdf.

Cunningham-Parmeter, K. (2016). From Amazon to Uber: Defining employment in the modern economy. Boston University Law Review, 96(5), 1673-1728. https://ssrn.com/abstract=2761577.

Dalzell, T., \& Victor, T. (2012). The New Partridge Dictionary of Slang and Unconventional English. London: Routledge.

Dazzi, D. (2019). Gig economy in Europe. Italian Labour Law E-Journal, 12(2), 67-122. https://doi. org/10.6092/issn.1561-8048/9925.

De Groen, W. P. \& Maselli, I. (2016). The impact of the collaborative economy on the labour market. CEPS Special Report No. 138. https:// www.ceps.eu/wp-content/uploads/2016/06/ SR138CollaborativeEconomy_0.pdf.

De Stefano, V. (2016). The rise of the just-in-time workforce: On-demand work, crowdwork, and labor protection in the gig-economy. Comparative Labor Law \& Policy Journal,. Comparative Labor Law \& Policy Journal, 37(3), 471-504. https://www. researchgate.net/publication/305163826_The_Rise of_the_Just-in-Time_Workforce_On-Demand_ 
Work_Crowdwork_and_Labor_Protection_in the Gig_Economy.

Dudley, G., Banister, D., \& Schwanen, T. (2017). The rise of Uber and regulating the disruptive innovator. Political Quarterly, 88(3), 492-499. https://doi. org/10.1111/1467-923X.12373.

Edelman, B. G. \& Luca, M. (2014, 10 January). Digital discrimination: The case of Airbnb.com. SSRN Electronic Journal. https://doi.org/10.2139/ ssrn.2377353.

Einav, L., Farronato, C., \& Levin, J. (2016). Peer-topeer markets. Annual Review of Economics, $8(1)$, 615-635. https://doi.org/10.1146/annureveconomics-080315-015334.

Estlund, C. (2018). What should we do after work? Automation and employment law. Yale Law Journal, 128(2), 254-326. https://doi.org/10.2139/ ssrn.3007972.

Etzioni, A. (2018). Benefits for gig workers. Challenge, 61(3), 255-268. https://doi.org/10.1080/05775132.2 018.1477475 .

Foote, D. A. \& Folta, T. B. (2002). Temporary workers as real options. Human Resource Management Review, 12(4), 579-597. https://doi.org/10.1016/S10534822(02)00069-4.

Frenken, K., van Waes, A., Pelzer, P., Smink, M., \& van Est, R. (2019). Safeguarding public interests in the platform economy. Policy and Internet, 12(3), 400425. https://doi.org/10.1002/poi3.217.

Friedman, G. (2014). Workers without employers: Shadow corporations and the rise of the gig economy. Review of Keynesian Economics, 2(2), 171-188. https://doi. org/10.4337/roke.2014.02.03.

Gereffi, G. (2011). Global value chains and international competition. The Antitrust Bulletin, 56(1), 37-56. https://doi.org/10.1177/0003603X1105600104.

Goodwin, M., \& Maconachie, G. (2011). Minimum labour standards enforcement in Australia: Caught in the crossfire? Economic and Labour Relations Review, 22(2), 55-80. https://doi. org/10.1177/103530461102200204.

Graham, M., \& Shaw, J. (2017). Towards a Fairer Gig Economy. London: Meatspace Press.

Holley, S. (2014). The monitoring and enforcement of labour standards when services are contracted out. Journal of Industrial Relations, 56(5), 672-690. https://doi.org/10.1177/0022185614523277.

Hyman, L. (2018). Temp: How American Work, American Business, and the American Dream Became Temporary. New York: Viking.

Irani, L. (2015, 16 January). Justice for "data janitors". Public Books. https://www.publicbooks.org/justicefor-data-janitors/

Jäger, G., Zilian, L. S., Hofer, C., \& Füllsack, M. (2019). Crowdworking: Working with or against the crowd? Journal of Economic Interaction and Coordination, 14(4), 761-788. https://doi.org/10.1007/s11403-01900266-1.

James, P. (2014). Urban Sustainability in Theory and Practice. London: Routledge. https://doi. org/10.4324/9781315765747.
Jiang, H. \& Zhang, X. (2019). An experimental model of regulating the sharing economy in China: The case of online car hailing. Computer Law \& Security Review, 35(2), 145-156. https://doi.org/10.1016/j. clsr.2018.12.008.

Jones, D. (2011). Cambridge English Pronouncing

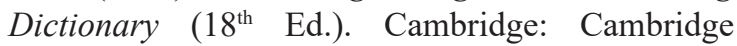
University Press.

Kaine, S. \& Josserand, E. (2019). The organisation and experience of work in the gig economy. Journal of Industrial Relations, 61(4), 479-501. https://doi. org/10.1177/0022185619865480.

Kalleberg, A. \& Dunn, M. (2016). Good jobs, bad jobs in the gig economy. Perspectives on Work, 10-14. http://lerachapters.org/OJS/ojs-2.4.4-1/index.php/ PFL/article/viewFile/3112/3087.

Kaplan, R. A., \& Nadler, M. L. (2015). Airbnb: A case study in occupancy regulation and taxation. University of Chicago Law Review Dialogue, 82. https:// heinonline.org/HOL/Page?handle=hein.journals/ uchidial $82 \&$ id $=103 \&$ div $=\&$ collection $=$

Kennedy, J. V. (2016, 18 April). Three paths to update labor law for the Gig economy. Information Technology \& Innovation Foundation. https://itif. org/publications/2016/04/18/three-paths-updatelabor-law-gig-economy.

Khumalo, B. (2012). Defining economics in the twenty first century. International Advances in Economic Research, 18(1), 128-129. https://doi.org/10.1007/ s11294-011-9327-y.

Koutsimpogiorgos, N, van Slageren, J., Herrmann, A., \& Frenken, K. (2019). Conceptualizing the Gig economy and its regulatory problems. Policy \& Internet, 12(4), 525-545. https://doi.org/10.1002/ poi3.237.

Kuhn, K. M. \& Maleki, A. (2017). Micro-entrepreneurs, dependent contractors, and instaserfs: Understanding online labor platform workforces. Academy of Management Perspectives, 31(3), 183-200. https:// doi.org/10.5465/amp.2015.0111.

Lepanjuuri, K., Wishart, R., \& Cornick, P. (2018). The Characteristics of Those in the Gig Economy. London: Department for Business, Energy and Industrial Strategy. http://hdl.voced.edu. $\mathrm{au} / 10707 / 451902$.

Li, S., Tavafoghi, H., Poolla, K., \& Varaiya, P. (2019). Regulating TNCs: Should Uber and Lyft set their own rules? Transportation Research Part B: Methodological, 129, 193-225. https://doi. org/10.1016/j.trb.2019.09.008.

Li, Y., \& Ma, L. (2019). What drives the governance of ride-sharing? A fuzzy-set QCA of local regulations in China. Policy Sciences, 52(4), 601-624. https:// doi.org/10.1007/s11077-019-09359-x.

Lima, V. (2019). Towards an understanding of the regional impact of Airbnb in Ireland. Regional Studies, Regional Science, 6(1), 78-91. https://doi.org/10.10 $80 / 21681376.2018 .1562366$.

Liu, J.. (2019, August 31). Companies that pay gig workers the most, from Airbnb to Costco. CNBC. https:// www.cnbc.com/2019/08/31/companies-that-pay- 
gig-workers-the-most-from-airbnb-to-costco.html.

Lloyd, A. (2017). Uber worked and underpaid: How workers are disrupting the digital economy. Information, Communication \& Society, 20(12), 1799-1801. https://doi.org/10.1080/1369118x.2017.1340972

Lund, S. \& Tyson, L. (2018, May/June). Globalization is not in retreat: Digital technology and the future of trade. Foreign Affairs. https:// heinonline.org/HOL/Page?handle=hein.journals/ fora97\&id=554\&div $=\&$ collection $=$

Marshall, A. (2013). Principles of Economics. London: Palgrave Macmillan. https://doi. org/10.1057/9781137375261.

McKee, D. (2017). The platform economy: Natural, neutral, consensual and efficient? Transnational Legal Theory, 8(4), 455-495. https://doi.org/10.1080/2041 4005.2017.1416516.

Manyika, J., Lund, S., Bughin, J., Robinson, K. Mischke, J., \& Mahajan, D. (2016). Independent work: Choice, necessity, and the gig economy. McKinsey \& Company. https://doi.org/10.1093/jicru/nd1025.

Mentzer, J. T. (2004). Fundamentals of Supply Chain Management: Twelve Drivers of Competitive Advantage. California: Sage Publications, Inc.

Minifie, J. (2016, 13 April). Peer-to-peer pressure policy for the sharing economy. Grattan Institute. https:// grattan.edu.au/report/peer-to-peer/.

Minter, K. (2017). Negotiating labour standards in the gig economy: Airtasker and Unions New South Wales. Economic and Labour Relations Review, 28(3), 438454. https://doi.org/10.1177/1035304617724305.

Munkøe, M. M. (2017). Regulating the European sharing economy: State of play and challenges. Intereconomics, 52(1), 38-44. https://doi. org/10.1007/s10272-017-0641-3.

Newcomer, E. (2020, 25 March). Uber and Airbnb lobby for Gig worker bailout. Bloomberg. https://www. bloomberg.com/news/articles/2020-03-25/uber-andairbnb-lobby-for-gig-worker-bailout.

Nurvala, J.-P. (2015). 'Uberisation' is the future of the digitalised labour market. European View, 14(2), 231-239. https://doi.org/10.1007/s12290-0150378-y.

Oei, S.-Y. (2018). The trouble with gig talk: Choice of narrative and the worker classification fights. Law and Contemporary Problems, 81(3), 107-136. https://scholarship.law.duke.edu/lcp/vol81/iss3/6/.

Oei, S.-Y. \& Ring, D. M. (2019). The tax lives of Uber drivers: Evidence from internet discussion forums. Columbia Journal of Tax Law, 8(2), 56-112. https:// doi.org/10.7916/cjtl.v8i2.2842.

Parigi, P., \& Ma, X. (2016). The gig economy. XRDS: Crossroads, The ACM Magazine for Students, 23(2), 38-41. https://doi.org/10.1145/3013496.

Park, M. (2019). The sharing economy, regulations, and the role of local government. International Journal of Tourism Cities, 6(1), 158-174. https://doi. org/10.1108/IJTC-08-2019-0122.

Pawlicz, A. (2019). Pros and cons of sharing economy regulation. Implications for sustainable city logistics. Transportation Research Procedia, 39, 398-404. https://doi.org/10.1016/j.trpro.2019.06.042

Pelzer, P., Frenken, K., \& Boon, W. (2019). Institutional entrepreneurship in the platform economy: How Uber tried (and failed) to change the Dutch taxi law. Environmental Innovation and Societal Transitions, 33, 1-12. https://doi.org/10.1016/j.eist.2019.02.003.

Pettersen, L. (2017). Rating mechanisms among participants in sharing economy platforms. First Monday, 22(12). https://doi.org/10.5210/fm.v22i12.7908.

Ljungholm, D. P. (2018). Employee-employer relationships in the gig economy: Harmonizing and consolidating labor regulations and safety nets. Contemporary Readings in Law and Social Justice, 10(1), 144-150. https://doi.org/10.22381/CRLSJ10120188.

PwC. (2015). Sharing or Paring? Growth of the Sharing Economy. https://www.pwc.com/hu/en/kiadvanyok/ assets/pdf/sharing-economy-en.pdf.

Ravenelle, A. J. (2019). Hustle and Gig (1 ${ }^{\text {st }}$ Ed.). California: University of California Press. https://doi. org/10.2307/j.ctvcwp0kc.

Risak, M. \& Prassl, J. (2016). Uber, TaskRabbit and Co: Platforms as employers? Rethinking the legal analysis of crowdwork. Comparative Labor Law and Policy Journal, 37(3), 619652. http://www.labourlawresearch.net/sites/ default/files/papers/15FEB\%20Prassl_Risak\%20 Crowdwork\%20Employer\%20post $\% 20$ review\%20 copy.pdf.

Rogers, B. (2015). Employment as a legal concept. SSRN Electronic Journal. https://doi.org/10.2139/ Ssrn. 2641305.

Samuelson, P. A. (1997). Study Guide to Accompany Economics (16 ${ }^{\text {th }}$ Ed.). New York: McGraw-Hill College.

Schor, J. (2014, October). Debating the sharing economy. Great Transition. https://greattransition.org/ publication/debating-the-sharing-economy.

Schor, J. (2018). Dependency and Precarity in the Sharing Economy. Sefton-Williams Memorial Lecture, Boston College. https://cirhr.library.utoronto.ca/ sites/cirhr-edit.library.utoronto.ca/files/sefton lectures/seftonwilliamslecture_4th_2018_schor.pdf.

Schwellnus, C., Geva, A., Pak, M., \& Veiel, R. (2019). Gig economy platforms: Boon or bane? In Organisation for Economic Co-Operation and Development Department Working Paper 1550, 1-33. https://doi. org/10.1787/fdb0570b-en.

Shukla, R. K., Garg, D., \& Agarwal, A. (2011). Understanding of supply chain. International Journal of Engineering Science and Technology (IJEST), 3(3), 2059-2072. https://www.researchgate.net/ publication/50946316_UNDERSTANDING_OF SUPPLY_CHAIN_A_LITERATURE_REVIEW.

Sinclair, M. (2016). Fair and efficient regulation of the sharing economy. Economic Affairs, 36(2), 204-211. https://doi.org/10.1111/ecaf.12179.

Slee, T. (2017). What's Yours is Mine: Against the Sharing Economy. New York: OR Books. https://doi. org/10.2307/j.ctt1bkm65n.

Snider, L. (2018). Enabling exploitation: Law in the gig economy. Critical Criminology, 26(4), 563-577. 
https://doi.org/10.1007/s10612-018-9416-9

Snyder, H. (2019). Literature review as a research methodology: An overview and guidelines. Journal of Business Research, 104, 333-339. https://doi. org/10.1016/j.jbusres.2019.07.039.

Stanford, J. (2017). The resurgence of gig work: Historical and theoretical perspectives. The Economic and Labour Relations Review, 28(3), 382-401. https:// doi.org/10.1177/1035304617724303.

Stewart, A. \& Stanford, J. (2017). Regulating work in the gig economy: What are the options? Economic and Labour Relations Review, 28(3), 420-437. https:// doi.org/10.1177/1035304617722461.

Sundararajan, A. (2014, 14 January). Peer-to-peer businesses and the sharing (collaborative) economy: Overview, economic effects and regulatory issues. In The Power of Connection: Peer-to-Peer Businesses. https://docs. house.gov/meetings/SM/SM00/20140115/101613/ HHRG-113-SM00-20140115-SD003-U1.pdf.

Tan, K. H., Denton, P., Rae, R., \& Chung, L. (2013). Managing lean capabilities through flexible workforce development: A process and framework. Production Planning and Control, 24(12), 10661076. https://doi.org/10.1080/09537287.2011.6460 13.

Veen, A., Kaine, S., Goods, C., \& Barratt, T. (2020). The 'gigification' of work in the $21^{\text {st }}$ Century. In P. Holland \& C. Brewster (Eds.), Contemporary Work and the Future of Employment in Developed Countries (pp. 15-32). Routledge. https://doi. org/10.4324/9781351034906-2.

Wahyuningtyas, S. Y. (2019). Self-regulation of online platform and competition policy challenges: A case study on Go-Jek. Competition and Regulation in Network Industries, 20(1), 33-53. https://doi. org/10.1177/1783591719834864.

Wegmann, J., \& Jiao, J. (2017). Taming Airbnb: Toward guiding principles for local regulation of urban vacation rentals based on empirical results from five US cities. Land Use Policy, 69, 494-501. https://doi. org/10.1016/j.landusepol.2017.09.025.

Wiener, M., Cram, A., \& Benlian, A. (2019). Technologymediated control legitimacy in the gig economy:
Conceptualization and nomological network. In R. Hirschheim, A. Heinzl, \& J. Dibbern (Eds.), Information Systems Outsourcing: The Era of Digital Transformation ( $5^{\text {th }}$ Ed.). Berlin: Springer. https://doi.org/10.1007/978-3-030-45819-5_16.

Williams, C. C. \& Horodnic, I. A. (2017). Regulating the sharing economy to prevent the growth of the informal sector in the hospitality industry. International Journal of Contemporary Hospitality Management, 29(9), 2261-2278. https://doi. org/10.1108/IJCHM-08-2016-0431.

Yaraghi, N. \& Ravi, S. (2017, 17 March). The current and future state of the sharing economy. SSRN Electronic Journal. https://doi.org/10.2139/ssrn.3041207

Yuana, S. L., Sengers, F., Boon, W., \& Raven, R. (2019). Framing the sharing economy: A media analysis of ride-sharing platforms in Indonesia and the Philippines. Journal of Cleaner Production, 212, 1154-1165. https://doi.org/10.1016/j. jclepro.2018.12.073.

Zhang, C. (2019). China's new regulatory regime tailored for the sharing economy: The case of Uber under Chinese local government regulation in comparison to the EU, US, and the UK. Computer Law \& Security Review, 35(4), 462-475. https://doi.org/10.1016/j. clsr.2019.03.004.

Zhang, N. \& Kien, S. S. (2019). Understanding the legitimacy challenges for sharing economy disruptors: A topic modeling approach. $40^{\text {th }}$ International Conference on Information Systems, ICIS 2019, 1. https://aisel. aisnet.org/icis2019/business_models/business_ models/16/.

Zutshi, A., \& Grilo, A. (2019). The emergence of digital platforms: A conceptual platform architecture and impact on industrial engineering. Computers and Industrial Engineering, 136, 546-555. https://doi. org/10.1016/j.cie.2019.07.027.

Zwick, A. (2018). Welcome to the gig economy: Neoliberal industrial relations and the case of Uber. GeoJournal, 83(4), 679-691. https://doi.org/10.1007/s10708-0179793-8. 